\title{
EDITORIAL NOTE ON RIGHT VENTRICULAR HYPERTROPHY
}

It has long been clear to me, and no doubt to many others, that extreme right axis deviation (large SI and RIII with insignificant RI and SIII) is common in many forms of pulmonary stenosis and other congenital heart diseases, much rarer in mitral stenosis (where a common finding is a small $R$ in lead I and a larger R in leads II and III, the rRR type), and quite unusual in chronic pulmonary disease. The more detailed knowledge of right ventricular preponderance obtained with chest leads has not greatly changed this impression.

The papers recently published in this journal by Goodwin (1952), Trounce (1952), and Woods (1952) have provided an opportunity to test this in more detail. None of these three included in their paper the actual size of the R and S waves in lead V1, to which, following Bain and Redfern (Brit. Heart J., 10, 9, (1948) I have paid particular attention. They have, however, kindly provided me with these figures and from them I have worked out average sizes and percentage distributions.

When cases vary so much the average is little more than an abstraction, but it gives some useful picture before looking at the more accurate though more complex range of variation: Table I shows the results of these calculations and also includes the normal figures given by Leatham (Brit. Heart $J ., 12,217,1950)$, and figures for normals and for the right ventricular hypertrophy of pneumoconiosis given by Thomas (Brit. Heart J., 10, 282, 1948). It will be seen that there is close agreement among these and that the normal, including children (but probably not infants), is an $R$ wave of about $5 \mathrm{~mm}$. or a little less and an $\mathrm{S}$ wave twice this size, $10 \mathrm{~mm}$.

TABLE I

Average Size of R ANd S in Lead V1

\begin{tabular}{|c|c|c|c|c|c|c|c|}
\hline & \multirow{2}{*}{\multicolumn{3}{|c|}{ Normals }} & \multicolumn{4}{|c|}{ Right Ventricular Hypertrophy } \\
\hline & & & & \multirow{2}{*}{$\begin{array}{c}\begin{array}{c}\text { Pulmonary } \\
\text { Disease }\end{array} \\
\begin{array}{c}\text { Thomas } \\
\text { (1948) }\end{array}\end{array}$} & \multirow{2}{*}{$\begin{array}{c}\text { Mitral } \\
\text { Stenosis } \\
\text { Trounce } \\
\text { (1952) }\end{array}$} & \multicolumn{2}{|c|}{$\begin{array}{l}\text { Congenital Heart } \\
\text { Disease }\end{array}$} \\
\hline & $\begin{array}{c}\text { Leatham } \\
(1950)\end{array}$ & $\begin{array}{c}\text { Goodwin } \\
\text { (1952) }\end{array}$ & $\begin{array}{l}\text { Thomas } \\
\text { (1948) }\end{array}$ & & & $\begin{array}{c}\text { Goodwin } \\
\text { (1952) }\end{array}$ & $\begin{array}{r}\text { Woods } \\
\text { (1952) }\end{array}$ \\
\hline $\begin{array}{l}\mathbf{R} \text { (in } \mathrm{mm} .) \\
\mathbf{S} \text { (in. } \mathbf{m m} \text {.) }\end{array}$ & $\begin{array}{r}3 \cdot 7 \\
10 \cdot 0\end{array}$ & $\begin{array}{r}5 \cdot 0 \\
10 \cdot 0\end{array}$ & $\begin{array}{r}4 \cdot 4 \\
12 \cdot 0\end{array}$ & $\begin{array}{r}4 \cdot 4 \\
13 \cdot 3\end{array}$ & $\begin{array}{l}4 \cdot 1 \\
4 \cdot 7\end{array}$ & $\begin{array}{r}12 \cdot 5 \\
4 \cdot 0\end{array}$ & $\begin{array}{r}12 \cdot 5 \\
2 \cdot 0\end{array}$ \\
\hline
\end{tabular}

In pneumoconiosis, and this can probably be taken as representative of most chronic pulmonary diseases, there is little difference in spite of the gross right ventricular hypertrophy. In mitral stenosis the $R$ wave has become no larger but the $S$ wave has become smaller, so that the $R / S$ ratio is not far from unity instead of less than a half.

In the right ventricular hypertrophy of congenital heart disease there is close agreement between the figures of Goodwin and of Woods and the $\mathrm{R}$ wave has become much larger, $12.5 \mathrm{~mm}$., and the $\mathrm{S}$ wave much smaller, $2-4 \mathrm{~mm}$., so that the $R / S$ ratio is over 4 .

The detailed figures of Goodwin, Trounce, and Woods, on which these conclusions are based, are given in Table III, and in a more convenient form as percentages in Table II, where the cases of right ventricular hypertrophy of Goodwin and of Woods have been combined. From this it will be seen that the $R$ wave is fairly small in the normal and in mitral stenosis, being less than $10 \mathrm{~mm}$. 
TABLE II

Percentage Distribution of Size of R and S in Lead V1

\begin{tabular}{|c|c|c|c|c|c|c|c|c|c|c|c|c|c|c|}
\hline \multirow[b]{3}{*}{$\begin{array}{l}\text { Normal } \\
\text { (Goodwin) }\end{array}$} & & & & & \multicolumn{10}{|c|}{ Size of $R$ and $S$ in $\mathrm{mm}$. } \\
\hline & & & & & & $\begin{array}{l}0 \\
1\end{array}$ & $\begin{array}{l}2 \\
3\end{array}$ & $\begin{array}{l}4 \\
5\end{array}$ & $\begin{array}{l}6 \\
7\end{array}$ & $\begin{array}{l}8 \\
9\end{array}$ & $\begin{array}{l}10 \\
11\end{array}$ & $\begin{array}{l}12 \\
13\end{array}$ & $\begin{array}{l}14 \\
15\end{array}$ & $\begin{array}{c}\text { Over } \\
15\end{array}$ \\
\hline & . &.. & $\begin{array}{l}. \\
.\end{array}$ & $\begin{array}{l}. . \\
.\end{array}$ & $\begin{array}{l}\mathbf{R} \\
\mathbf{S}\end{array}$ & $\begin{array}{l}8 \\
4\end{array}$ & $\begin{array}{r}28 \\
6\end{array}$ & $\begin{array}{r}30 \\
9\end{array}$ & $\begin{array}{l}13 \\
13\end{array}$ & $\begin{array}{r}17 \\
9\end{array}$ & $\begin{array}{r}2 \\
17\end{array}$ & $\begin{array}{r}0 \\
15\end{array}$ & $\begin{array}{r}\mathbf{0} \\
\mathbf{1 7}\end{array}$ & $\begin{array}{r}2 \\
10\end{array}$ \\
\hline $\begin{array}{l}\text { Mitral stenosis } \\
\text { (Trounce) }\end{array}$ & $\begin{array}{l}. . \\
\text {. }\end{array}$ & $\because$. & $\because$. & $\because$. & $\begin{array}{l}\mathbf{R} \\
\mathbf{S}\end{array}$ & $\begin{array}{l}25 \\
31\end{array}$ & $\begin{array}{l}31 \\
19\end{array}$ & $\begin{array}{l}18 \\
17\end{array}$ & $\begin{array}{r}11 \\
9\end{array}$ & $\begin{array}{l}3 \\
5\end{array}$ & $\begin{array}{l}3 \\
9\end{array}$ & $\begin{array}{l}6 \\
4\end{array}$ & $\begin{array}{l}3 \\
6\end{array}$ & $\begin{array}{l}\mathbf{0} \\
\mathbf{0}\end{array}$ \\
\hline \multicolumn{2}{|c|}{$\begin{array}{l}\text { Fallot's tetralogy, etc. } \\
\text { (Goodwin and Woods) }\end{array}$} & $\begin{array}{l}. \\
\cdots\end{array}$ & $\ddot{n}$ & $\begin{array}{l}. \cdot \\
.\end{array}$ & $\begin{array}{l}\mathbf{R} \\
\mathbf{S}\end{array}$ & $\begin{array}{r}4 \\
61\end{array}$ & $\begin{array}{r}2 \\
12\end{array}$ & $\begin{array}{l}2 \\
\mathbf{5}\end{array}$ & $\begin{array}{r}7 \\
10\end{array}$ & $\begin{array}{l}7 \\
1\end{array}$ & $\begin{array}{l}4 \\
3\end{array}$ & $\begin{array}{l}5 \\
3\end{array}$ & $\begin{array}{l}9 \\
1\end{array}$ & $\begin{array}{r}60 \\
4\end{array}$ \\
\hline
\end{tabular}

TABLE III

Size of R AND S Waves IN LeAd V1

\begin{tabular}{|c|c|c|c|c|c|c|c|c|c|c|c|c|c|c|c|c|c|c|}
\hline & \multicolumn{18}{|c|}{ Size in $\mathrm{mm}$. } \\
\hline & & 0 & 1 & 2 & 3 & 4 & 5 & 6 & 7 & 8 & 9 & 10 & 11 & 12 & 13 & 14 & 15 & $>15$ \\
\hline \multirow{2}{*}{$\begin{array}{l}\text { Normals (53) } \\
\text { (Goodwin) }\end{array}$} & $\mathbf{R}$ & 0 & 4 & 7 & 8 & 7 & 9 & 3 & 4 & 5 & 4 & 0 & 1 & 0 & 0 & 0 & 0 & 1 \\
\hline & $\mathbf{S}$ & 0 & 2 & 1 & 2 & 1 & 4 & 4 & 3 & 4 & 1 & 7 & 2 & 5 & 3 & 5 & 4 & 5 \\
\hline \multirow{2}{*}{$\begin{array}{l}\text { Fallot's tetralogy, etc. (38) } \\
\text { (Goodwin) }\end{array}$} & $\mathbf{R}$ & 0 & 1 & 0 & 1 & 0 & 1 & 2 & 1 & 2 & 1 & 0 & 0 & 0 & 3 & 1 & 3 & 20 \\
\hline & $\mathbf{S}$ & 14 & 1 & 4 & 2 & 2 & 2 & 3 & 1 & 0 & 0 & 0 & 1 & 3 & 0 & 0 & 1 & 2 \\
\hline \multirow{2}{*}{$\begin{array}{l}\text { Fallot's } t \\
\text { (Woods) }\end{array}$} & $\mathbf{R}$ & 0 & 3 & 1 & 0 & 0 & 1 & 0 & 3 & 1 & 2 & 2 & 2 & 0 & 1 & 4 & 0 & 32 \\
\hline & $\mathbf{S}$ & 27 & 10 & 2 & 3 & 0 & 0 & 3 & 2 & 0 & 1 & 2 & 0 & 0 & 0 & 0 & 0 & 2 \\
\hline \multirow{2}{*}{$\begin{array}{l}\text { Mitral stenosis (65) } \\
\text { (Trounce) }\end{array}$} & $\mathbf{R}$ & 4 & 12 & 14 & 6 & 7 & 5 & 6 & 1 & 1 & 1 & 2 & 0 & 3 & 1 & 2 & 0 & 0 \\
\hline & $\mathbf{S}$ & 15 & 5 & 8 & 4 & 3 & 8 & 1 & 5 & 0 & 3 & 4 & 2 & 3 & 0 & 4 & 0 & 0 \\
\hline
\end{tabular}

in 96 and 88 per cent respectively, but in Fallot's tetralogy $R$ is $10 \mathrm{~mm}$. or more in 78 per cent (and $6 \mathrm{~mm}$. or more in 92 per cent).

The $S$ wave is fairly large in normals being $4 \mathrm{~mm}$. or more in 90 per cent and $8 \mathrm{~mm}$. or more in 68 per cent; on the other hand in mitral stenosis and in Fallot's tetralogy the $S$ wave is less than $8 \mathrm{~mm}$. in 76 and 88 per cent respectively. Thus mitral stenosis is in an intermediate position resembling the normal as regards the $R$ wave and Fallot's tetralogy as regards the $S$ wave. 